\title{
THE STUDY OF POWER DYNAMICS AND IDENTITY CRISIS IN SORAYYA KHAN'S CITY OF SPIES
}

\author{
Shaista Shahzadi ${ }^{1 *}$, Muhammad Hanif ${ }^{2}$, Rao Akmal Ali ${ }^{3}$, Asmat A. Sheikh ${ }^{4}$, Mehnaz Kousar ${ }^{5}$ \\ ${ }^{1 *}, 3$ Lecturer, and NUML, Multan, Pakistan; ${ }^{2}$ COMSATS, Vehari, Pakistan; ${ }^{4}$ Associate Professor, The Women \\ University, Multan, Pakistan; ${ }^{5}$ Student, NUML, Multan, Pakistan. \\ Email: ${ }^{1 *}$ shahzadi.shaista@yahoo.com, ${ }^{2}$ muhammadhanif@ ciitvehari.edu.pk
}

Article History: Received on $13^{\text {th }}$ February 2021, Revised on $2^{\text {nd }}$ May 2021, Published on $5^{\text {th }}$ May 2021

\begin{abstract}
Purpose of the study: This study investigates the identity crises and power relations drawing upon Michel Foucault's theory of power tracing the impacts of power dynamics. The study investigates how power dynamics operate in the novel; what is the nature of these power relations; and how the mode of resistance emerges and in what ways by keeping the concept of power and identity by Michel Foucault.

Methodology: This part follows the qualitative method in which Sorayya Khan's City of Spies is analyzed through Foucault's theory of power. The theoretical background of this research is drawn from the concept of Power which is running in all works of Foucault.

Main Findings: This study has examined the novel from a Foucauldian perspective, which posits that Power is everywhere and it comes from everywhere. For him, it is Power which/that shapes everything whether it is Truth or Identity. Foucault sees power as all-around invisibility that exposes rather than encloses like the panopticon. The society he believes works as a panopticon in which the power effectively induces in the subjects a state of conscious and permanent visibility that assures the automatic functioning of power.
\end{abstract}

Applications of this study: This study can be applied to power dynamics literature.

Novelty/Originality of this study: The current interpretation of the novel only sees it as a bildungsroman i.e., as a journey of a girl around the political reality of her era. This present study strives to change it by investigating through the lens of power dynamics and its consequent effect on consciousness leading to an identity crisis. The present study will strengthen the interpretation of the novel as a political novel and will illustrate the effects of the political on the human psyche.

Keywords: Crisis, Dynamics, Power, Foucault, Identity.

\section{INTRODUCTION}

The present research aims to elaborate on the power dynamics and identity crisis existing in Sorayya Khan's City of Spies from the concept of Power given by Michel Foucault. The concept of Power is running in all his works because Sorayya Khan's selected text is a historical socio-political novel that shows how changing power relations in society affect the psyche of its main characters (Shamsie, 2017). Power dynamics means that power itself is a dynamic force that evolves and does not remain stagnant, which in turn entails that power dynamics refer to the change of power relations in any given society (Mohr \& Brooke, 2009) and the term identity crisis in the context of the research refers to the condition that arises when the means of resistance are offered to the existing power relations of society. This research asserts that power relations portrayed in the novel lead to an identity crisis in its main characters, primarily Aliya Shah and Sadiq. The study investigates how power dynamics or changing power relations operate in the novel; what is the nature of these power relations and how the modes of resistances emerge and in what ways by keeping in mind the concept of power and identity by Foucault.

Power and its historical influence on a community and its people have been a prominent debate of the 20th century (Shamsie, 2016) but only Foucault solely delves into the psyche of the human subject that how changing power dynamics affect them. Theorists like Edward Said, Michel Foucault, and Noam Chomsky have deliberated on the problem. Moreover, prominent philosophers have delved into the question of the historical materialization of power in society in one way or the other. All of them have looked upon the past that how it materializes the future and in doing so creates certain hierarchies in society. Nonetheless, they partly analyzed the past from an explicit lens of power. However, the work of Michel Foucault is central in this regard who says that it is 'Power' which shapes everything whether it's 'Truth' or 'Identity'. According to Foucault power make us who we are. There was a big change in the concept of power after he gave his concept of power, which is different from the concepts of power given at that time. For him, Power is diffused instead of coercive (Gaventa, 2003).

Foucault claims that power is inside every individual and is represented by the sovereign representation of control or dominance rather than as something which cannot be avoided. Power is present in everything and is present in everything. It also comes from everything, thus making it a free concept rather than done by any organization (Foucault 1982). For him, power is a system of truth that is constructed by society and is keep on changing. Foucault utilized the concept of power with information, whoever so ever has information or truth, he is powerful. 
Truth is a concept which comes with its limitations. It also increases the intensity of power. All societies have their truth. Truth is a social construction of ideas or concepts; it is a type of information that is accepted as true by society. Thus, who so ever says the truth has the power. (Foucault, 1991). Foucault is one of those few scholars who saw the positive side of power as well otherwise most of the scholars see it as a negative concept, as something which is used to take other's rights. Whereas, it can be something positive or vital for the public or individuals (Gaventa, 2003). Foucault (1994) states that:

'People should stop considering power as a negative force and start seeing the positive side of power. As through power, we can produce real and norms and values of truth.' (Foucault, 1994)

For maintaining proper social order, it is essential to have power. Foucault in the $18^{\text {th }}$ century noticed another force through which power is involved in bringing a change in society. Power is not a negative force and to move power from being a negative force to being a positive force is used to construct a society.

\section{Statement of Problem}

The novel is a caricature of a historical power struggle that focuses on how changing power relations affect individual dispositions. Moreover, the novel focuses on how the struggle to these changing power relations or power dynamics add up to the conflict of an identity crisis. The present study undertakes to examine and evaluate these presuppositions in the light of Michel Foucault's concept of power and identity.

\section{Objectives of the Study}

Following are the objectives of this study:

- To discover power dynamics operating in Sorayya Khan's City of Spies

- To illustrate modes of resistance to these changing power relations and their consequent effects on its main characters, primarily, Aliya and Sadiq.

\section{LITERATURE REVIEW}

This section constitutes a review of the work already done on City of Spies by different critics. Most of the secondary sources available on the novel see it as a bildungsroman and not as a political novel which is still relevant. The reviewers of the novel believe that the novel primarily is a coming of an age story about a girl's journey about the events taking place around her (Ibrahimi, 2017; Rahman, 2020). Some of them acknowledge the effects of imperialism and history on the girl's consciousness but do not do so to the extent to argue that it the predominant power dynamics that shape the consciousness of the main characters of the novel. None of the reviews was proper researches that ascertain their claims either through textual frame or analysis through a theoretical lens (Foucault, 1982). Therefore, the research gap exists to determine the main propositions of the present study (Nader, 2012).

The global power-play has a deep and everlasting impact on an individual life. Annie Zaidi argues that "The novel City of Spies is a story of a struggle of a young girl in her difficult times who is finding her place in her family and the world" (Zaidi, 2015). The present study aims to prove and illustrate these assertions at length especially how political power dynamics affect individual consciousness. The novel is the story of a time of martial law by General Muhammad Zia-ulHaq who is named as general and who arrested the Prime Minister of his time, which is a depiction of the use of power in the name of religion (Khan, 2015). The story is full of secrets of a family and how global power plays an important role in the destruction of individual lives. The main character, Aliya is a half-half, which means an American and a Dutch and she always tried to know her identity that from which side she belongs to and people also accept her in that way as her fellows used to bully her in the name of racism. Unlike Annie, the present study uses an elaborate framework to check its assertions using a Foucauldian theory of power.

Chakrabarty (2017) studied the exchange of memory and history of three books of khan i.e., Noor (2003), Five Queen's Road (2009), and City of Spies (2015). In all these novels Khan has shown the violence done in the past. In the first one, he has shown the independence of Bangladesh, in the second novel he showed independence of India, and in the third novel, she showed the dominant power over Pakistan, respectively. Being a daughter of two different nationals she is worried about her father's heritage in her work. The misfortune and the procedure of recovery and the qualities that hold people established in the past are for the most part prevailing worries in her fiction. Singular decisions are all the time overwhelmed by political real factors (Rostami-Povey \& Poya, 2007). The current examination expects to demonstrate and show these affirmations finally. Particularly, how political force elements influence singular decisions by utilizing the Foucauldian hypothesis of intensity for dissecting the content of the novel.

The past, to Ilona Yousuf, is a reality constructing force. She sees the novel with a Foucauldian lens. The City of Spies, she thinks, is a coming of an age novel and the events are only there to strengthen the reality of the bildungsroman. She says that the cold war and the national conflict work only as of the backdrop to the personal. She says the novel transcends politics and race. To strengthen Aliya's views of the world around her, Ilona says that Sorayya focuses more on how history or the events taking around us shape our consciousness. She writes, "Khan's power as a novelist is in way of how past shape our mindset and attitudes and pushes the readers to question things or past which is ignored before" 
(Yousuf, 2015). Here she is arguing that it is history that shapes human consciousness just like Foucault has argued that to understand our material reality we need to examine the past, as it is the past that has shaped our present. Here, Ilona gives credit to Sorayya for bringing out those events that have shaped our present as many of us do not know that the extreme radicalism that we see today is remains of the cold war and Zia era (Yousuf, 2015).

History and consciousness go hand in hand. Ilona's article establishes the basis of this research by establishing the link of consciousness with history, though it does not deliberate at length on how this happens in the novel and also does not give the novel its dues credit as a political novel, which it deserves (Yousuf, 2015). The narrative does revolve around a single consciousness that is Alia who is also the narrator, but this research argues that the events which are shown through her consciousness have their intrinsic value as well. The novel lays out the political framework of that era both domestically and internationally and by doing that it illustrates how it shapes the personal, which Ilona also acknowledges. The present study aims to prove and illustrate these assertions at length, especially how political power dynamics affect individual consciousness. Unlike Ilona, the present study uses an elaborate framework to check its assertions using a Foucauldian theory of power which helps better assess the text in the light of history's effect on human consciousness.

The truth and its impact encompass everything that comes in its way. It conquers the mind, the government, and even a kitchen equally. Masha Hamilton in the Washington Post reaffirms Ilona's position as she also sees it as a coming of an age story. She writes, "Sorayya Khan neatly incorporates the international complexities of the times into Aliya's efforts to understand what makes her singular — and what makes her part of a tribe" (Hamilton, 2017). Masha like Ilona sees the historical events as a backdrop under which the consciousness of the protagonist is developed. She says, "Truth — or rather, too little of it - impacts what is happening not only in government offices but in Aliya's kitchen" (Hamilton, 2017). Alia as the protagonist of the novel is struggling to make sense of the truth around her. What Masha misses out on in the novel is that the novel is also realizing its reader through its reexamination of history from a child's perspective that how they are missing out on truth or truths around them have been manipulated throughout history.

The City of Spies is a story of changing sides and conflicting loyalties. Turner reviews City of Spies as an autobiographical novel as the character of Aliya is a representation of Khan herself. Khan is also a half-half identity as her mother was Dutch and her father was a Pakistani. Then the life of the main character of the novel Aliya becomes difficult with the death of Hanif. Aliya's effort to find her identity and fit in a specific tribe is a story of today's world where there are a lot of marriages between people of different nations. By commenting on City of Spies, he says "This is a story of a girl who is searching for her identities and her loyalties kept on changing" (Turner, 2015). Thus, this study aims to illustrate this identity crisis and display of power keeping in view the Foucauldian theory of power.

The political impacts the personal. It erases boundaries between the home and the world. Hasnain (2016) sees the novel Cities of Spies as a story of goodness in which humanity is survived irrespective of all the hurdles in the past. There is a lot of work done of coincidence but yet the truth is always more than what is told (Foucault, 2021). For one it is an impressive unfinished story of someone's life whereas for others it a life story. This novel shows the truth of Aliya which includes a lot of up and downs in politics and finishing lines between the home and the world. When a reader reads it, he or she must get vibes of as if something is going to happen no matter he does not in reality or not. The story might be remembered as a story of your neighbourhood when people remember someone for the short dress but no doubt an 11-year-old girl must also be remembered. This study aims to illustrate and prove this view by keeping in view the Foucauldian theory of power.

The novel is a story of existing in two different worlds, simultaneously. Elen Turner reviews City of Spies and says that Khan's third novel is a mind-boggling and moving assessment of, in addition to other things i.e., American dominion through the eyes of a little youngster (Turner, 2015). Aliya Shah is 11 years of age. Her mom is Dutch, her dad is Pakistani. Aliya goes to an American school with the offspring of negotiators and, apparently, spies. Her closest companion is a blonde young lady named Lizzy. Aliya exists between two universes. Her life was changed when the family hireling was slaughtered. The entirety of this is set against an entangled political foundation: it's the 1970s; Bhutto has been dismissed, and Gen. Zia has accepted administration. Khan's treatment of race, class, and American government can feel cumbersome in places. Along these lines, this investigation plans to investigate the individual character emergency and force elements in the novel through the Foucauldian hypothesis of intensity.

This novel portrays a vivid description of political life. Aliya endeavour to understand the occasions that shook and formed her immaturity and her nation. At the end of the novel, thirty months have passed and Pakistan has spun into disorder the Prime Minister has been hanged, and the faithful General Zia has initiated the Islamization of Pakistan's legitimate and political frameworks. Khan gives a long 20 pages epilogue set in the current day, and afterward a postcontent as well, however, the impact to me was that of opening another section in Aliya's life as opposed to giving a fulfilling finish to the story. We discover that the grown-up Aliya, at last, comprehends occasions of those months, however, while we see how the past affected Aliya's inclinations and her decision of calling, there is a tempting nonappearance concerning Aliya's character and character as a grown-up. The peruse can without much of a stretch accept that occasions occurred as they did, even while perceiving that some of them are anecdotal. Despite its conventional deficiencies, City of Spies is an intriguing novel that tells a story as geopolitically resounding of now as of the time wherein it was set. 
Malik (2020), however, supports the proposition of this research. It argues that the novel affects the national and international consciousness of the present time by laying out concerns that are still relevant. The review hints that the historical events or concerns shown in the novel are still shaping our reality until this present date. The review sees the modern world searching for truths where there are only a few as there is no objective reality (Malik, 2020). The review prompts the reader to make sense of its current political reality through understanding how it was shaped in the past. The present study takes the assertions made in the review to an academic enquiry to see how the political consciousness of the present time was shaped by altering the power dynamics of the past.

\section{METHODOLOGY}

This study has employed the qualitative method in which Sorayya Khan's City of Spies is analyzed through Foucault's theory of power. The theoretical background of this research is drawn from the concept of Power which is running in all works of Foucault. Although, he has not given any specific theory of Power because Foucault was quick to separate himself from giving a theory of Power because the thought of hypothesis recommended a setting free, esteem unbiased, and an authentic perspective on power's activity, impacts, and results. Instead of hypothesis, he gives a concept of power which, he contends that Power is everywhere and it comes from everywhere (Foucault 1982). For him, identity is also linked to Power which is also running in all his works.

Foucault kept altogether changing his research advantages and strategies all through his scholarly vocation, which likewise implies that his utilization of the ideas of power and the subject modified throughout his compositions. To recognize this assorted variety and the different changes in his reasoning, the researcher breaks down his works by isolating them into three unique stages, be specific archaeological, genealogical, and aesthetic/ethnic since it is regularly sawed that Michel Foucault's scholarly profession had these three primary stages (Bernauer and Rasmussen,1988; Gaventa, 2003). Notwithstanding, it ought to be recollected that this division has been made by later scholars, not Foucault himself. Foucault himself saw his work as to some degree conflicting, contending that the structure "a garbled, muddled jumble" (Foucault, 1980).

However, the work of Michel Foucault is central in this regard who says that it is Power that shapes everything whether it is Truth or Identity. According to Foucault, power makes us who we are. There was a big change in the concept of power after he gave his concept of power, which is different from the concepts of power given at that time. For him, Power is diffused instead of coercive (Gaventa, 2003).

Foucault claims that power is inside every individual and is represented by the sovereign representation of control or dominance rather than as something which cannot be avoided. Power is present in everything and is present in everything. It also comes from everything, thus making it a free concept rather than done by any organization (Foucault, 1998). For him, power is a system of truth that is constructed by society and is keep on changing. Foucault utilized the concept of power with information, whoever has information or truth, and he is powerful. Truth is a concept which comes with its limitations. It also increases the intensity of power. All societies have their truth. Truth is a social construction of ideas or concepts; it is a type of information that is accepted as true by society. Thus, who so ever says the truth has the power (Foucault, 1991). Foucault is one of those few scholars who saw the positive side of power as well otherwise most of the scholars see it as a negative concept, as something which is used to take other's rights. Whereas, it can be something positive or vital for the public or individuals: 'People should stop considering power as a negative force and start seeing the positive side of power. As through power, we can produce real and norms and values of truth' (Foucault, 1994). For maintaining proper social order, it is essential to have power. Foucault in the $18^{\text {th }}$ century noticed another force through which power is involved in bringing a change in society. Power is not a negative force and to move power from being a negative force to being a positive force is used to construct a society.

\section{DISCUSSION/ANALYSIS}

This chapter endeavours to answer the research questions by exploring indeterminate meanings about Power and identity crisis in the novel City of Spies. This chapter is mainly subjected to exploring those camouflaged meanings which are confusing for readers to get a conclusion about the writer's agenda of Power dynamics and identity crisis. This chapter is divided into two parts. In this chapter, the novel City of Spies is critically discussed in terms of power dynamics and identity crisis keeping in mind the concept of Foucault.

Power discourse constitutes the novel. Sorayya Khan in her novel, City of Spies, evokes questions in her reader's mind such as, is power truly within the hands of the individuals of society and not actually within the governing heads as we all suppose? Is power all that matters? Is everything that matters in this world simply controlled by who has the most power? Khan's "A City of Spies" is a narrative in a socio-political environment, taking place within the capital of Pakistan, Islamabad. The political climate is set during the 1970s when Prime Minister Zulfiqar Ali Bhutto was about to be hanged and the General Zia ul Haq had taken over power and therefore a martial law had been imposed. The novel talks about all the events that take place when the family moves back to Islamabad during the martial rule from Lahore and the discovery of the death of their servant's sons, Hanif, leaves the young teen with a completely new perspective an identity crisis of sorts. 
"As a rule, truth is as wide and all-encompassing as you let it be, and there is always more of it." (han, 2015, p. 5)

So says 11-year-old narrator Aliya Shah in the opening pages of Sorayya Khan's "City of Spies," and that sentiment could be repeated on nearly every page of this intriguing coming-of-age story.

Khan examines the impact of power from a micro perspective. Sorayya utilizes the theoretical concepts of Power dynamics and its effects on identity crises in her story. "There has been a coup," my father said after a moment. "The prime minister is in custody and martial law has been declared" (Khan, 2015, p. 12). As 11-year-old Aliya says and dictates the events that take place in Sorayya Khans, "A City of Spies", the above quote is evident and synergistic to Foucault's belief. Prime Minister Zulfiqar Ali Bhutto had been declared as a murderer and martial law had been imposed. A shift in the Power dynamics stirs up the pot in which the life of most Pakistanis stood stationary, wreaking havoc for nearly all. These emotions are well portrayed by Khan through the lens of Aliya.

The above quote is similar to the Marxist view where Power had been imposed and oppressively used against the nation. For example in another situation Aliya says the following; "the general decreed there would be no political activity and prohibited gatherings of more than five people in public spaces. Newspapers were marked by white columns, but in between sat thin strips of newsprint bland enough to pass a censor's scrutiny" (Khan, 2015, p. 25). This explains exactly what was contrary to what Foucault believed that power when in the hands of entities and institutions show not to be oppressed or superimposed by force onto people instead he glances and views power through the microscope, he views it as the relationship between individuals of society and the effect the power has on them. That is exactly what Khan does in her book, she gives the audience a microscopic view into the lives that were greatly affected by the shift in power dynamics through the martial rule, she chooses an alternative to the bird's eye view. "God was everywhere, but so was the general" (Khan, 2015, p. 27).

The supposition of power and its imperative domination on the individuals and groups of society is exactly the philosophy behind that Khan portrays in her book. With the country being in a coup, Aliya and her family feel more congested than ever, almost claustrophobic in the sense that the powerful were everywhere.

Power dynamics affect the individual regardless of their age. The effect that the shift in power dynamics produced is evident and can be pointed out about Foucault in Sorayya's book, "My mother guessed that Hanif was eight. "Whatever it is, the boy is far too young to be distraught over the country's politics," my father declared" (Khan, 2015, p. 37). Sorayya shows through the eyes of eight-year-old Hanif, son of Sadiq, the attachment one develops with those when power is in the right hands, the concern the nation develops when those that rightfully deserve power in their hands are overthrown and executed, she again utilizes Foucault theory and uses a somewhat of a metaphorical magnifying glass on the matter and opts to show via a smaller yet more impactful lens. Sadiq is shown as someone who has more power in the sense that he influenced Aliya the main character of the novel and his character also helped her to get out of her identity crisis by the death of Hanif.

Hanif's life changes with a detached incident of power change. In another place, Khan shows the same fact in the following passage. "After Sadiq returned to the servants' quarters, my father recounted what he'd heard. According to Jamila, who'd been with him when he learned the news, Hanif wept on hearing of the general deposing the prime minister, and overnight, a boy who'd had to be threatened to learn his prayers claimed his father's janamaz, prayer carpet, as his own. Now he spent more time on the janamaz than in school or on the cricket pitch. My father asked, "You know that Hanif was named for a famous Pakistani batsman, right?" He said that upon hearing the news of the prime minister's indictment for the murder of a political opponent, Hanif had given away his cricket bat. My father's grip tightened on the arms of his chair, and he seethed that our great chief martial-law administrator's crimes extended to destroying a young boy's love for cricket" (Khan, 2015, p. 80). How a child of just eight years develops a connection with right control of power and how he prays to the Almighty for deliverance is a glimpse into the emotions of the nation, as in the words of Aliya, "Hanif spent all his time on his father's janamaz communing with God because, God knows, only He could set things right" (Khan, 2015, p. 102). According to Foucault, Relations of power "are indissociably from a discourse of truth, and they can neither be established nor function unless a true discourse is produced, accumulated, put into circulation, and set to work. Power cannot be exercised unless a certain economy of discourses of truth functions in, based on, and thanks to, that power. "Little men, unelected men stand no chance without the hand of greater power." (Khan, 2015, p. 155). Khan sheds light on the theorists' beliefs through the protagonists' father that when power is taken and given to those who will use to only oppress, the nation is fated to not succeed.

Power in the novel manifests itself in a complex way. The unusual route chosen by Sorayya Khan is displaying Foucault's theory and beliefs of power are remarkable. She chooses not to focus on the main source of power i.e., the general and his oppressive or 'orthodox' acts; she chooses to keep that focus sidelined and lets her readers experience the shift that was felt by most Pakistanis due to the assurgency of the martial law. In Khan's grasp, the savagery and misfortune in Aliya's homegrown environmental factors read as a minor reverberation of the nation's turbulent, grisly political scenes. The Prime Minister, toppled by the military, is blamed for the homicide of a political adversary and is therefore detained. Papers are taken over by the public authority, the mail shows up effectively opened, social events of more than five individuals are precluded by law, and Islamabad is creeping with spies. "Nobody understood what they were doing since the greater part of them were thought to be spies". She uses Foucault's way of thinking, where force 
was generally perceived as the limit of a specialist to force his will over the desire of the frail, or the capacity to drive them to do things they don't wish to do. In this sense, power is perceived as ownership, as something possessed by people with significant influence. In any case, as Foucault would see it, power isn't something that can be claimed, but instead something that acts and shows itself with a particular goal in mind; it is more a methodology than a belonging. Force should be breaking down as something which flows, or as something which just capacities as a chain. Where force is utilized and practised through a net-like association and people are the vehicles of force, not its places of use.

Identity crisis creeps through the weak breaks of characters' personalities. The crucial thought arising out of the entirety of his work is that the favoured spot to notice the force in real life is the relations between the individual and the general public, particularly its establishments. Thusly, Foucault concentrates on how different organizations apply their force on gatherings and people, and how the last attest their personality and protection from the impacts of force. Therefore, within the above context, as is evident from Sorayya Khan's story, she deals with a power shift and showcases the macroscopic power through a microscopic lens. She deals with the same phenomena that when certain institutions i.e., the martial rule of the general exert their power on groups, in this case, the people of Pakistan, and individuals, in this case, the main protagonists of her story, an affirmance of identity takes place to the latter. Sorayya shifts the focus from the power being exerted on a national level to more of that being exerted on a nationalist's level. In her story, she first portrays Aliya as someone who hasn't yet grasped her identity well. She feels split between being half and half i.e., half Dutch and half Pakistani. "I still blamed the prime minister. Whether it was reasonable or not, I held him personally responsible for my discomfort with what I was-half-and-half, mixed, Pakistani, whatever.” (Khan, 2015, p. 212).

Aliya's sense of self is lost. Concerning Aliya's daily school bus trips and the indecency that took place there every day, the following words truly express how being a Pakistani made her feel not so comfortable in her skin, "I didn't tell my parents. A small part of me believed that Pakistanis deserved to be spit upon....... going to a Pakistani school, would have been worse." (Khan, 2015, p. 233). Another example is the conversation that took place between the best friends when asking where she is from, "Shah and Simon, that placed us in seats assigned next to each other. The first time she asked me where I was from, I told her Austria because I was born there. The second time, I told her Holland because that was where my mother was from. The last time, I confessed, "Pakistan, too." "Which one is it?" she finally asked, clearly confused. "All of them, actually," I replied, feeling caught in a lie, but now trying to tell the truth. "That's so cool!" Lizzy said. "Not really" (Khan, 2015, p. 244). Aliya is unable to address the topic of where she's from; she differently answers Austria (the nation of her introduction to the world), Holland and Pakistan. Her character is put to a fierce test each day, for her school, generally, is inviting to the individuals who are white, those with the last name Bhutto, or those, as Aliya, who can pass. Therefore, in the attempts to find a homage for herself, she adopts the life of her best friend Lizzy, and tries her utmost best to blend in, to such an extent she takes measures to her own hands that she keeps her two worlds separate, her home where she is Aliya and it doesn't matter whom she is whether a half-andhalf or a Pakistani trying to be like an American, and the second being the world of her fantasy where she gets to live life like her best friend, eating foods coming in from the commissary, watching shows on the television that do not necessarily begin with an Islamic preamble, wearing jeans, etc.

Aliya finds herself in a flux of accepting and rejecting herself. In context to her desire to adapt to her best friends' lifestyle, she even enjoyed being called nicknames native to Lizzy's origin, "Leeyaa. I loved the way her nickname for me rolled off her tongue. The two syllables instead of three. It made me less myself," (Khan, 2015, p. 203). Sorayya then shows how a traumatic experience within her household changes things for Aliya, the moment Hanif was killed that too by an American her best friend's mother Anne Simon, in her words she felt Pakistani. Sorayya thus shows very skillfully, the macroscopic facade at a minute distinctive level, how Americans had killed so many Pakistanis in the past and were continuously conspiring against them, Sorayya displays that motive through an 11-year-old eye. She first makes her audience relates to the character, sympathize with her, develop a connection with her, so much to the extent that we feel as we are one. Every emotion that spikes within her are felt more deeply to us as readers as the story progresses, such as her inclination towards Sadiq, her deep empathy for him, and much more. For her, Sadiq wasn't just a house 'servant' who used to help her in learning Urdu. Therefore, her identity was established as being more Pakistani than she ever was due to a shift in 'power' through an unfortunate incident as in Aliya's words, "Because of Hanif's death I was more Pakistani than ever...” (Khan, 2015, p. 288).

Therefore, the discussion concludes that Sorayya knits the two concepts that form the base of Foucault's philosophy in her socio-political interpretation. It displayed the show of power dynamics and how it affected the main characters of the novel. It also portrayed how Aliya and Sadiq showed resistance to changing power dynamics which lead to an identity crisis.

\section{CONCLUSION}

To conclude, this novel expands the force elements and character emergency existing in Sorayya Khan's City of Spies from the idea of Power given by Michel Foucault. The idea of Power is running in the entirety of his works because Sorayya Khan's chosen text is a verifiable socio-political novel that shows how changing power relations in the public eye influence the mind of its principal characters. Power elements imply that power itself is a unique power that advances and doesn't stay stable, which thusly involves that power elements allude to the difference in power relations in some random society and the term personality emergency with regards to the exploration alludes to the condition that 
emerges when the methods for obstruction are offered to the current force relations of society. This study states that power relations depicted in the novel lead to a personality emergency in its principal characters, essentially Aliya Shah and Sadiq. The examination explores how power elements or changing power relations work in the novel; what is the idea of these power relations and how the method of protection rises and in what ways by remembering the idea of power and personality by Foucault. The surprising course picked by Sorayya Khan is showing Foucault's concept and convictions of power are noteworthy. She decides not to concentrate on the primary wellspring of intensity for example the general and his abusive or 'standard' acts; she decides to maintain that centre sidelined and lets her readers experience the move that was felt by most Pakistanis because of the assurgency of the military law. In Khan's grasp, the violence and fiasco in Aliya's family unit natural variables read as a minor resonation of the countries violent, draining political scenes.

\section{LIMITATION AND STUDY FORWARD}

The study is limited to power dynamics and identity crisis; however, further study can be done on analyzing the novel linguistically by applying the theory of power by Fairclough.

\section{ACKNOWLEDGEMENT}

The credit goes to the writers solely as the work is done by their creativity.

\section{AUTHORS CONTRIBUTION}

The first author wrote the introduction, the second wrote the literature review and half part in the discussion, the third wrote the conclusion, the fourth did formatting according to APA style, the fifth did the formatting and the sixth did the suggested changes by the journal.

\section{REFERENCES}

1. Ali, S. (2018). The Analysis of Five Queen's Road by Sorayya Khan in the lens of Historiographic Metafiction (Doctoral dissertation, University of Management \& Technology).

2. Anjum, Z. (2015). "Kitaab Review of 'City of Spies: A Novel,' by Sorayya Khan.” Kitaab.

3. Chakrabarty, B. (2017)."Topography of Loss: Homeland, History and Memory in Sorayya Khan's Fiction." Asiatic: IIUM Journal of English Language and Literature,11(1), 86-101.

4. Cilano, C. N. (2013). Contemporary Pakistani fiction in English: Idea, nation, state. Routledge. https://doi.org/10.4324/9780203552247

5. Bernauer, J. and Rasmussen, D., eds. (1988). The Final Foucault, 11Cambridge, MA: MIT Press.

6. Foucault, M, Kelly \& Habermas, J. (1994). Critique and power: recasting the Foucault/Habermas debate. MIT press.

7. Foucault, M. (1980). Power/knowledge: Selected interviews and other writings, 1972-1977. Vintage.

8. Foucault, M. (1982). The subject and power. Critical inquiry, 8(4), 777-795. https://doi.org/10.1086/448181

9. Foucault, M. (1991). Politics and the study of discourse. In Burchell, G., Gordon, C. \& Miller, P. (Eds.), The Foucault effect: Studies in governmentality (pp. 53-72). Chicago, IL: University of Chicago Press.

10. Foucault, M. (1998) The History of Sexuality: The Will to Knowledge, London, Penguin.

11. Foucault, M. (2021). Intellectuals and power. In Language, counter-memory, practice (pp. 205-217). Cornell University Press.

12. Gaventa, J. (2003). Power after Lukes: An Overview of Theories of Power since Lukes and Their Application to Development. Brighton: Participation Group, Institute of Development Studies. https://www.powercube.net/wp-content/uploads/2009/11/power_after_lukes.pdf

13. Hamilton, M. (2017). A Young Woman Caught between Pakistan and the West. Retrieved from

14. Hasnain, S. (2016). City of Spies. Retrieved from https://www.slideshare.net/SheikhHasnain2/city-of-spiesby-sorayya-khan-62498585

15. Ibrahimi, N. (2017). Dynamics of Contentious Politics in Afghanistan, 2001-2016. PhD Thesis. The Australian National University.

16. Khan, S. (2015). City of Spies. Aleph Book Company

17. Khan, S. (2015). The Silence and Forgetting That Wrote NOOR. Journal of Narrative Politics, 1(2).

18. Khan, S. (2017). "City of Spies.” Kirkus Reviews.

19. Khan, S. (2017). City of Spies. Brilliance Audio.

20. Malik, J. (2020). Muslim Heterogeneity: Margins Becoming Centres of Muslim Power (Approx. 1300-1500). In Islam in South Asia (pp. 153-201). Brill. https://doi.org/10.1163/9789004422711_006

21. Mohr, John W. \& Brooke, N. (2009). Modeling Foucault: Dualities of power in institutional fields. Institutions and Ideology. Emerald Group Publishing Limited. https://doi.org/10.1108/S0733558X(2009)0000027009

22. Nader, L. (2012). Culture and dignity: Dialogues between the Middle East and the West. John Wiley \& Sons.

23. Rahman, T. (2020). Pakistani English. The Handbook of Asian Englishes, 279-296. https://doi.org/10.1002/9781118791882.ch11 
Humanities \& Social Sciences Reviews elSSN: 2395-6518, Vol 9, No 3, 2021, pp 153-160 https://doi.org/10.18510/hssr.2021.9317

24. Rostami-Povey, E., \&Poya, M. (2007). Afghan women: Identity and invasion. Zed Books. https://doi.org/10.5040/9781350218062

25. Shamsie, M. (2016). Pakistani English Novels in the New Millennium: Migration, Geopolitics, and Tribal Tales. New Soundings in Postcolonial Writing: Critical and Creative Contours, Cross/Cultures, 189, 149169. https://doi.org/10.1163/9789004329270_012

26. Shamsie, M. (2017). Pakistani-English Writing. In Oxford Research Encyclopedia of Literature. https://doi.org/10.1093/acrefore/9780190201098.013.69

27. Turner, E. (2015). Kitaab Review of 'City of Spies: A Novel,' by Sorayya Khan. Kitaab.

28. Yousuf, I. (2015). Book Review: City of Spies. Retrieved from https://newslinemagazine.com/magazine/b ook-review-city-of-spies/

29. Zaidi, A. (2015). Book Review: City of Spies. Retrieved from https://www.livemint.com/Leisure/LsyZsBTk N07B3kzIlUWOeI/Book-review-City-of-Spies.html 